\title{
UPAYA PENINGKATAN AKTIVITAS BELAJAR MATEMATIKA MELALUI COOPERATIVE LEARNING TIPE STUDENT TEAMS ACHIEVEMENT DIVISIONS
}

\author{
Gustina \\ Guru SMA Negeri 1 Sitiung \\ Email: gustinatitin58@gmail.com
}

\begin{abstract}
The purpose of this study was to increase student-learning activities in mathematics. This research was conducted in two cycles with three meetings; each cycle in this research includes planning, action, observation, and reflection. The researcher chose 25 students of class XII IPA 2 SMA N 1 Sitiung Semester 1 Academic Year 2015/2016 as research subjects. The results of the research in the first cycle, student activities in following material explanations reached 77,33\%, answering questions and solving questions on the exercises $61.33 \%$ and participating student activities answering questions in class discussions $54.67 \%$, but low on discussion activities in groups which only reached $37.33 \%$. Whereas in the second cycle, each indicator of student learning activities increased, activity in participating in learning at $84 \%$, discussing in groups reached $74.67 \%$, participating in answering and solving questions in exercises reached $88 \%$ and answering questions in class discussion 62,67\%. Based on the results of this research, it can be concluded that, the implementation of the STAD type cooperative learning model in class XII IPA2 SMA N 1 Sitiung could increase Mathematics learning activities.
\end{abstract}

Keywords: Learning activity, Cooperative Learning, Student Teams Achievement Divisions

\begin{abstract}
Abstrak
Tujuan penelitian ini adalah untuk meningkatkan aktivitas belajar matematika siswa. Penelitian ini dilaksanakan dalam dua siklus dengan tiga pertemuan; Setiap siklus dalam penelitian ini meliputi perencanaan, pelaksanaan tindakan, observasi, dan refleksi. Peneliti memilih 25 siswa kelas XII IPA 2 SMA N 1 Sitiung Semester 1 Tahun Ajaran 2015/2016 sebagai subjek penelitian. Hasil penelitian siklus I, aktivitas siswa dalam mengikuti penjelasan materi mencapai $77,33 \%$, menjawab soal dan menyelesaikan soal pada soal latihan $61,33 \%$ dan keaktifan siswa menjawab soal pada diskusi kelas 54,67\%, tetapi rendah pada kegiatan diskusi kelompok yang hanya mencapai 37,33\%. Sedangkan pada siklus II masing-masing indikator aktivitas belajar siswa meningkat, aktivitas mengikuti pembelajaran $84 \%$, berdiskusi berkelompok mencapai $74,67 \%$, berpartisipasi dalam menjawab dan memecahkan soal latihan soal mencapai $88 \%$ dan menjawab soal dalam diskusi kelas $62,67 \%$. Berdasarkan hasil penelitian dapat disimpulkan bahwa penerapan model pembelajaran kooperatif tipe STAD pada siswa kelas XII IPA2 SMA N 1 Sitiung dapat meningkatkan aktivitas pembelajaran Matematika.
\end{abstract}

Kata Kunci: Aktivitas Pembelajaran, Pembelajaran Kooperatif, Student Teams Achievement Di Division 


\section{PENDAHULUAN}

Permasalahan pada penelitian ini adalah rendahnya aktivitas siswa dalam belajar matematika disebabkan karena berbagai faktor, selain jenuh dengan banyaknya pelajaran yang harus dikuasai sebelum UN (Ujian Nasional) karena siswa merasa matematika adalah pelajaran yang abstrak yang sulit dimengerti, matematika penuh dengan rumus dan angka-angka yang membingungkan. Metode pembelajaran yang diterapkan guru, penggunaan media yang kurang relevan atau pekerjaan rumah yang banyak sehingga membuat siswa-siswa merasa kehilangan waktu istirahat dan kehilangan semangat belajar, yang berdampak pada rendahnya aktivitas belajar di kelas dan rendahnya pemahaman terhadap materi pelajaran yang diberikan. Oleh sebab itu peneliti menggunakan metode pembelajaran Cooperative Learning tipe Student Teams-Achievement Divisions (STAD) sebagai pemecahan masalah pembelajaran ini.

\section{Aktivitas Belajar}

Didalam aktivitas belajar ada beberapa prinsip yang berorientasi pada pandangan ilmu jiwa modern aktivitas didominasi oleh siswa. Aktivitas siswa tiidak cukup mendengarkan dan mencatat saja. Sperti yang diungkapkan oleh Diedrich dalam Sardiman (2000: 101) tentang interaksi dan motivasi belajar mengajar diantaranya:

1. Oral activities, seperti: mengatakan, merumuskan, bertanya, memberi saran, mengeluarkan pendapat, mengadakan wawancara, diskusi.

2. Mental activities, seperti: menanggapi, mengingat, pemecahan masalah, menganalisis, melihat, dan mengambil keputusan.

3. Emosional activities, seperti: menaruh minat, merasa bosan, gembira, bersemangat, bergairah, berani, tenang, gugup.

Slameto (2003:2) bahwa "Belajar adalah proses yang dilakukan seseorang untuk memperoleh suatu perubahan tingkah laku yang baru secara kuseluruhan, sebagai hasil pengalamannya sendiri dalam interaksi dengan lingkunganya Menurut Nikson yang dikutip oleh Mulyardi (2003:3) mengemukakan bahwa;

"Pembelajaran matematika adalah upaya yang membantu peserta didik mengkontruksikan konsep-konsep atau prinsip-prinsip matematika dengan kemampuannya sendiri melalui proses internalisasi sehingga konsep atau prinsip itu terbangun kembali"

\section{Model Pembelajaran Kooperatif Tipe STAD}

Menurut Muslimin (2000: 20-25) pelaksanaan Cooperative Learning dalam proses pembelajaran dapat dilakukan dengan menerapkan salah satu tipenya. Ada beberapa tipe Cooperative Learning diantaranya adalah Student Teams Achievment Division (STAD), Teams Games Tournamens (TGT), Cooperative Integrated Reading And Composition (CIRC), Learning Together, Jigsaw, Group Investigation (GI),dan Think Pair Square(TPSq).

Muslimin (2000) menjelaskan kegiatan pembelajaran model STAD terdiri dari 7 tahap, yaitu:

Tahap 1: Persiapan Pembelajaran.

a. Materi

Materi pembelajaran dalam belajar kooperatif dengan menggunakan model

STAD dirancang sedemikian rupa untuk pembelajaran secara berkelompok. 
Sebelum menyajikan materi pembelajaran, dibuat Lembar Diskusi Siswa (LDS) yang akan dipelajari kelompok, dan lembar jawaban dan lembar kegiatan kelompok tersebut.

b. Menempatkan Siswa dalam Kelompok

Menempatkan siswa dalam kelompok yang masing-masing kelompok terdiri dari empat orang dengan cara mengurutkan siswa dari atas ke bawah berdasarkan kemampuan akademiknya dan daftar siswa yang telah diurutkan tersebut dibagi menjadi empat bagian.

c. Menentukan Skor Dasar

Skor dasar merupakan skor rata-rata pada kuis sebelumnya. Jika mulai menggunakan STAD setelah memberikan tes kemampuan prasyarat/tes pengetahuan awal, maka skor tes tersebut dapat dipakai sebagai skor dasar, selain itu nilai ujian harian sebelumnya juga bisa digunakan sebagai skor dasar.

Tahap 2: Penyajian Materi

Tahap penyajian materi ini menggunakan waktu sekitar 20-45 menit. Setiap pembelajaran dengan model ini selalu dimulai dengan penyajian materi oleh guru. Sebelum menyajikan materi pembelajaran, guru dapat memulai dengan menjelaskan tujuan pembelajaran, memberikan motivasi untuk berkooperatif, menggali pengetahuan prasyarat dan sebagainya.

Tahap3: Kegiatan Belajar Kelompok

Dalam setiap kegiatan belajar kelompok digunakan lembar kegiatan, lembar tugas, dan lembar kunci jawaban masing-masing dua lembar untuk setiap kelompok, dengan tujuan agar terjalin kerja sama di antara anggota kelompoknya. Lembar kegiatan dan lembar tugas disahkan setelah kegiatan kelompok selesai dilaksanakan.

Tahap 4: Pemeriksaan terhadap Hasil Belajar Kelompok

Pemeriksaan terhadap hasil belajar kelompok dilakukan dengan mempresentasikan hasil kegiatan kelompok di depan kelas oleh wakil dari setiap kelompok. Disini peneliti memodifikasinya dengan memilih satu kelompok untuk mempresentasikan hasil belajar kelompok mereka, kelompok yang lain hanya menanggapi dan melengkapi jawaban penyaji.

Tahap 5: Siswa Mengerjakan Soal-Soal Tes secara Individual

Pada tahap ini setiap siswa harus memperhatikan kemampuannya dan menunjukkkan apa yang diperoleh pada kegiatan kelompok dengan cara menjawab soal tes tertulis dengan kemampuannya. Pada tahap ini siswa tidak diperkenankan bekerja sama.

Tahap 6: Pemeriksaan Hasil Tes

Pemeriksaan hasil tes dilakukan oleh guru dengan membuat daftar skor peningkatan setiap individu, yang kemudian dimasukkan menjadi skor kelompok. Tahap 7: Penghargaan Kelompok

Setelah diperoleh hasil kuis, kemudian dihitung skor peningkatan individual berdasarkan selisih perolehan skor kuis pendahuluan (skor dasar) dengan skor kuis terakhir. Pemberian penghargaan pada kelompok yang memperleh poin perkembangan kelompok tertinggi. 


\section{METODOLOGI}

\section{Lokasi dan Waktu Penelitian}

Penelitian ini dilaksanakan di SMA Negeri 1 Sitiung dengan subjek penelitian adalah siswa kelas XII IPA2 SMA N 1 Sitiung dalam mata pembelajaran Matematika semester 1 tahun pembelajaran 2015/2016 yang terdiri dari 25 orang siswa. Data penelitian berdasarkan sumbernya termasuk data primer. Waktu penelitian direncanakan dilaksanakan selama lebih kurang 3 bulan, yaitu dari bulan Oktober sampai Desember 2015.

\section{Prosedur Penelitian}

\section{Siklus 1}

\section{a. Rencana pemecahan masalah (planning)}

Persiapan yang peneliti lakukan untuk penelitian ini adalah: menentukan jadwal penelitian, menyusun materi penelitian, mempersiapkan perangkat penelitian yang terdiri dari RPP, LKS, pembagian kelompok, mempersiapkan buku sumber dan alat peraga (media) yang akan digunakan selama penelitian dan menyiapkan soal test akhir untuk tindakan tahap I.

\section{b. Pelaksanaan tindakan (action)}

Langkah-langkah pelaksanaan pembelajaran yang dipilih untuk memecahkan masalah rendahnya aktivitas belajar siswa adalah belajar melalui model pembelajaran kooperatif adalah sebagai berikut: Membentuk kelompok diskusi dengan kelompok yang heterogen. Siswa duduk pada kelompok masing-masing yang tempat duduknya telah diatur sebelum kegiatan belajar mengajar berlangsung. Siswa melakukan diskusi dalam kelompok, guru memberikan dorongan agar siswa berpartisipasi aktif supaya diskusi berjalan dengan lancar. Melakukan diskusi kelas tiap kelompok melaporkan hasil diskusi kelompoknya. Salah satu kelompok membacakan hasil diskusinya yang akan ditanggapi oleh kelompok lain. Guru memberikan ulasan atau penjelasan terhadap materi yang telah didiskusikan. Siswa mencatat hasil diskusi dan guru mengumpulkan laporan hasil diskusi satu perkelompok. Siswa melaksanakan test akhir pembelajaran.

\section{c. Pemantauan (observation)}

Pemantauan hasil observasi dilakukan oleh seorang observer yang akan mencatat aktivitas siswa selama pembelajaran berlangsung dan kemungkinan data sampingan yang merupakan informasi berguna dalam penelitian ini. Data pada tabel disusun berdasarkan data pada lembaran pengamatan, yaitu pengamatan dari aspek siswa tentang aktivitas yang dilakukan selama pembelajaran berlangsung yang meliputi: aktif mengikuti penjelasan materi. aktif berdiskusi dalam kelompoknya. Aktif berpartisipasi menjawab dan menyelesaikan soal di LKS. Aktif berpartisipasi menjawab pertanyaan dalam diskusi kelas.

\section{d. Refleksi}

Data yang dikumpulkan diolah secara kuantitatif (persentase) dan secara kualitatif (deskripsi dengan kata-kata). Dari refleksi ini akan tergambar hasil yang dicapai apakah rumusan masalah diterima atau ditolak. Pada bagian refleksi ini akan digambarkan pula kekurangan-kekurangan yang ditemukan pada siklus pertama. Kemudian dilakukan lagi untuk tindakan pada siklus kedua. Berdasarkan perenungan dari siklus pertama ini disusunlah rencana untuk siklus kedua. 


\section{Siklus ke II}

\section{Rencana pemecahan masalah (planning)}

Guru mempersiapkan perangkat pembelajaran. Merencanakan pembagian kelompok yang baru dengan pemberian nomor panggil untuk setiap siswa. Menggunakan model pembelajaran kooperatif tipe STAD. Mengumpulkan hasil diskusi kelompok diakhir diskusi untuk setiap siswa dan dinilai. Menyiapkan soal test akhir pembelajaran.

\section{Tindakan (Action)}

Strategi pembelajaran yang dipakai adalah model pembelajaran dengan langkah-langkah sebagai berikut: Membentuk kelompok diskusi baru. Siswa duduk pada kelompok masing-masing yang tempat duduknya telah diatur sebelum kegiatan belajar dimulai. Guru membagikan bahan ajar berupa LKS kepada siswa. Guru memberikan arahan agar siswa terlibat secara aktif dalam kerja kelompok. Siswa melakukan diskusi dalam kelompok, guru memberikan dorongan agar siswa berpartisipasi aktif. Melaksanakan diskusi kelas, tiap kelompok melaporkan hasil diskusi kelompoknya. Guru memberikan ulasan atau penjelasan terhadap materi yang disajikan agar siswa dapat menarik kesimpulan yang benar. Guru mengumpulkan hasil diskusi kelompok setiap siswa untuk dinilai. Guru melakukan tes akhir sebagai evaluasi terhadap materi yang telah didiskusikan.

\section{Pemantauan (Observation)}

Sebagaimana refleksi siklus pertama, data yang terkumpul pada lembaran observasi diolah secara kuantitatif dan kualitatif. Pada refleksi ini digambarkan hasil yang dicapai dan dibandingkan dengan siklus pertama apakah diperoleh kemajuan. Dengan siklus kedua ini maka akan diperoleh gambaran secara keseluruhan dan sekaligus mengetahui jawaban masalah atau pertanyaan yang diajukan.

\section{HASIL PENELITIAN DAN PEMBAHASAN \\ Deskripsi Hasil Penelitian Siklus I}

Deskripsi Hasil penelitian diuraikan dalam tahapan yang berupa siklussiklus pembelajaran yang dilakukan. Dalam penelitian ini pembelajaran ini dilakukan dalam dua siklus. Data Aktivitas Belajar Matematika Siklus I. Adapun hasil perhitungan observer terhadap aktivitas belajar siswa kelas XII IPA2 SMA N 1 Sitiung pada siklus I adalah sebagai berikut :

Tabel. 1. Hasil Observasi Aktivitas Belajar Matematika Siswa pada Siklus I

\begin{tabular}{|c|c|c|c|c|c|c|}
\hline \multirow{2}{*}{ No. } & \multirow{2}{*}{ Aktivitas Belajar } & \multicolumn{4}{|c|}{ Jumlah Siswa } & \multirow{2}{*}{$\%$} \\
\hline & & Pert.1 & Pert.2 & Pert. 3 & Rataan & \\
\hline 1 & Aktif mengikuti penjelasan materi & 17 & 19 & 22 & 19 & 77,33 \\
\hline 2 & $\begin{array}{l}\text { Aktif berdiskusi dalam } \\
\text { kelompoknya }\end{array}$ & 7 & 15 & 19 & 14 & 54,67 \\
\hline 3 & $\begin{array}{l}\text { Aktif berpartisipasi menjawab } \\
\text { dan menyelesaikan soal di LKS }\end{array}$ & 14 & 11 & 21 & 15 & 61,33 \\
\hline 4 & $\begin{array}{l}\text { Aktif berpartisipasi menjawab } \\
\text { pertanyaan dalam diskusi kelas. }\end{array}$ & 5 & 10 & 13 & 9 & 37,33 \\
\hline
\end{tabular}

Cat : Total jumlah siswa adalah 25 orang. 
Pada Tabel 1 terlihat bahwa aktivitas belajar kelas XII IPA2 SMA N 1 Sitiung pada siklus I dapat dikatakan aktivitas siswa tinggi mengikuti penjelasan materi hingga mencapai $77.33 \%$, menjawab pertanyaan dan menyelesaikan soal di LKS $61.33 \%$ dan aktivitas siswa cukup berpartisipasi menjawab pertanyaan dalam diskusi kelas 54.67\%, tapi rendah pada aktivitas berdiskusi dalam kelompok yang hanya mencapai angka $37.33 \%$. Atau dapat dilihat pada Gambar. 1 berikut:

Gambar 1. Hasil Observasi Aktivitas Belajar Siswa Siklus I

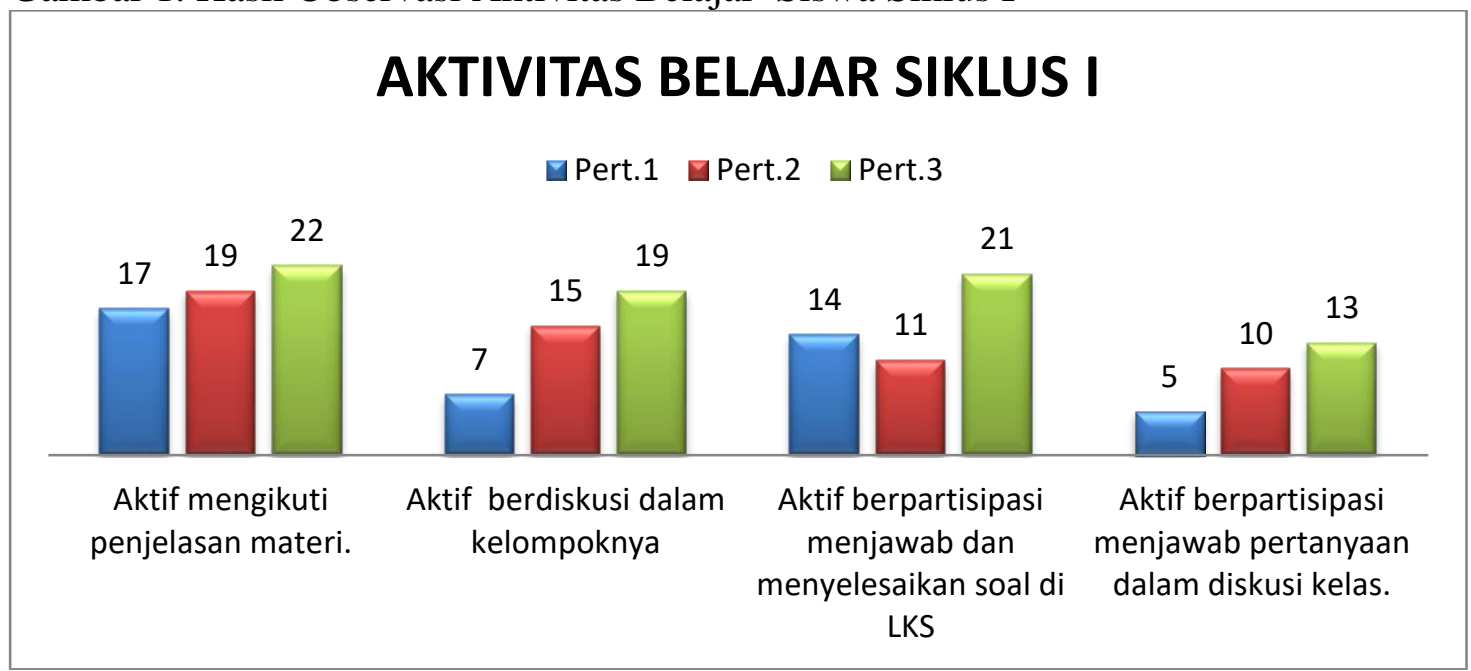

1. Refleksi Siklus I

Berdasarkan hasil pengamatan dari pelaksanaan pembelajaran ditemukan hal-hal seperti di bawah ini :

1) Siswa kurang mempersiapkan diri belajar dan belum mengerti penjelasan guru di awal pembelajaran yang mengakibatkan mereka masih ada yang bingung memahami pertanyan-pertanyaan yang ada dalam LKS

2) Sebagian besar siswa sangat tekun mengikuti penjelasan tentang Matriks , tapi aktivitas masih sangat rendah pada keaktivan berdiskusi dalam kelompok.

3) Sebagian besar Siswa sangat tertarik mengikuti sistem pembelajaran kooperatif tipe STAD.

\section{Hasil Penelitian Siklus II}

Pada siklus II, Hasil penelitian yang diperoleh adalah sebagai berikut :

1. Data Aktivitas Belajar Siswa kelas XII IPA2 SMA N 1 Sitiung Siklus II Berdasarkan data hasil pengamatan terhadapa aktivitas belajar siswa pada siklus II dapat dilihat pada Tabel.4 sebagai berikut :

Tabel. 2. Hasil Observasi Aktivitas Belajar Matematika siswa pada Siklus II

\begin{tabular}{|c|c|c|c|c|c|c|}
\hline \multirow{2}{*}{ No. } & \multirow{2}{*}{ Aktivitas Belajar } & \multicolumn{4}{|c|}{ Jumlah Siswa } & \multirow{2}{*}{$\%$} \\
\cline { 3 - 6 } & Pert.1 & Pert.2 & Pert.3 & Rataan & \\
\hline 1 & Aktif mengikuti penjelasan materi & 20 & 20 & 23 & 21 & 84,00 \\
\hline
\end{tabular}




\begin{tabular}{|c|l|c|c|c|c|c|}
2 & $\begin{array}{l}\text { Aktif berdiskusi dalam } \\
\text { kelompoknya }\end{array}$ & 17 & 19 & 20 & 19 & 74,67 \\
\hline 3 & $\begin{array}{l}\text { Aktif berpartisipasi menjawab } \\
\text { dan menyelesaikan soal di LKS }\end{array}$ & 20 & 21 & 25 & 22 & 88,00 \\
\hline 4 & $\begin{array}{l}\text { Aktif berpartisipasi menjawab } \\
\text { pertanyaan dalam diskusi kelas. }\end{array}$ & 14 & 15 & 18 & 16 & 62,67 \\
\hline
\end{tabular}

Cat : Total jumlah siswa adalah 25 orang.

Pada masing - masing item aktivitas belajar siswa yang diamati semuanya mengalami peningkatan, baik keaktifan mengikuti pembelajaran, berdiskusi dalam kelompok, berpartisipasi menjawab dan menyelesaikan soal dalam LKS maupun aktivitas menjawab pertanyaan dalam diskusi kelas.

Gambar 2. Hasil Observasi Aktivitas Belajar Matematika siswa Siklus II

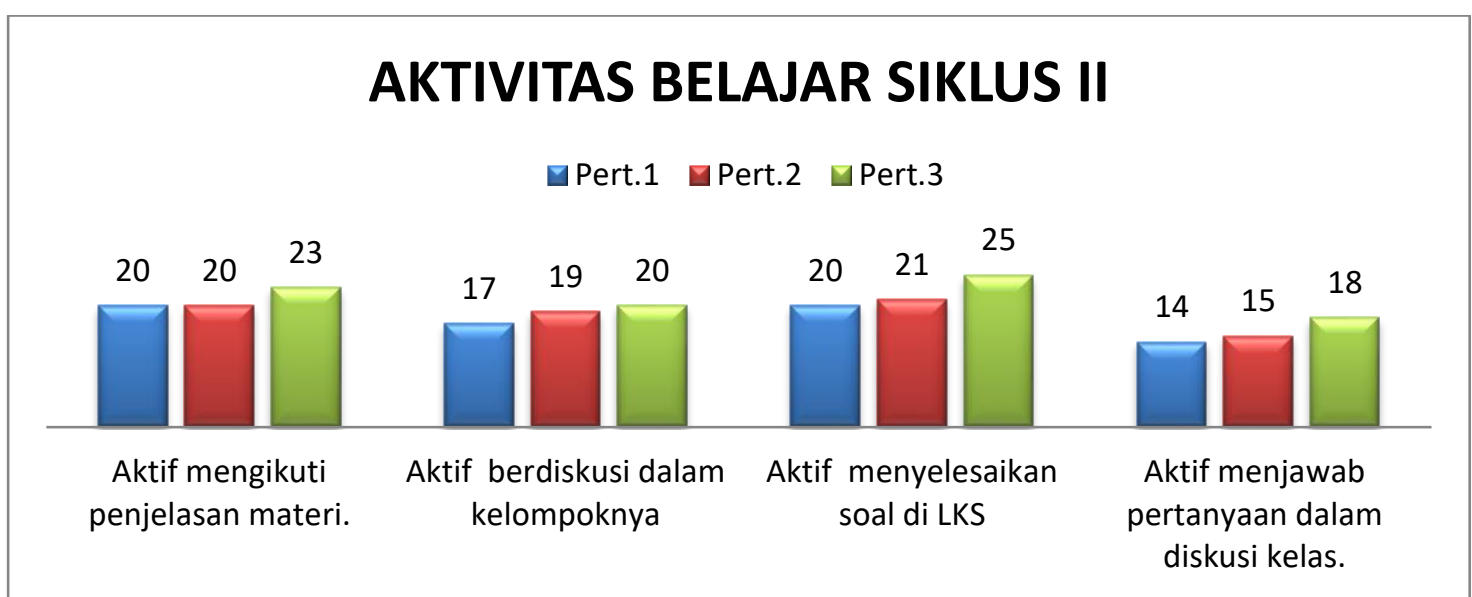

2. Refleksi Siklus II

Secara umum aktivitas siswa belajar matematika dengan menggunakan model pembelajaran kooperatif tipe STAD pada siklus kedua mengalami peningkatan dibanding siklus pertama. Pada siklus kedua ini tampak siswa mengalami peningkatan peningkatan pemahaman materi yang dipelajari. Perolehan nilai harian siswa pun mengalami peningkatan. Berdasarkan pengamatan terhadap aktivitas belajar matematika, maka pada siklus kedua ditemui hal-hal sebagai berikut :

1) Sebagian siswa telah menyiapkan diri belajar Matrik dengan menggunakan model pembelajaran kooperatif tipe STAD dengan menguasai materi-materi sebelumnya.

2) Siswa sudah terbiasa dengan model pembelajaran kooperati tipe STAD, sehingga keberlangsungan pembelajaran sesuai dengan rencana pelaksanaan pembelajaran.

3) Siswa sudah terbiasa berdiskusi baik di dalam kelompok kecil maupun di kelompok besar.

Perbandingan aktivitas belajar matematika siswa menggunakan Model pembelajaran kooperatif tipe STAD pada siklus I dan II, dapat dilihat pada Gambar 3. berikut: 
Gambar 3. Perbandingan Aktivitas Belajar Siswa Siklus I dan II

\section{Perbandingan Aktivitas Siklus I \& Siklus II}

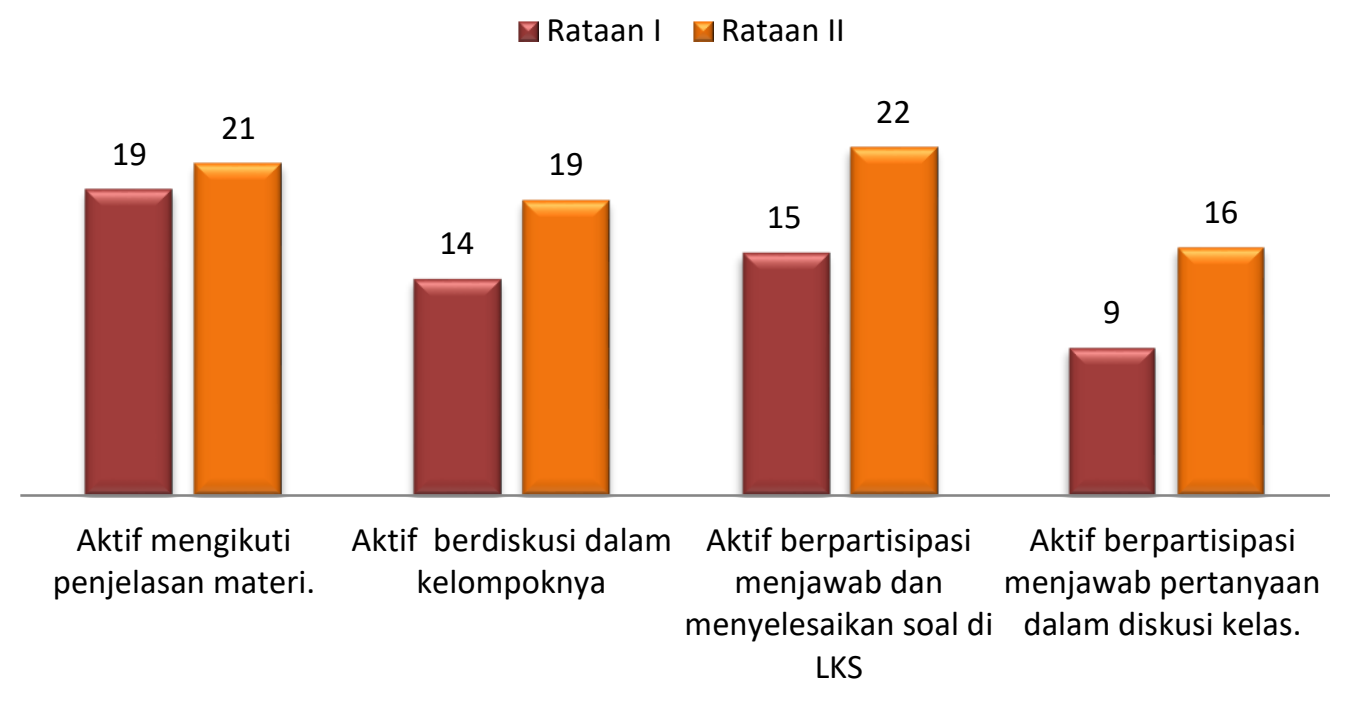

Dari Gambar 3. Di atas, tampak bahwa terjadi peningkatan aktivitas belajar siswa dari siklus I ke siklus II, walau tidak mengalami peningkatan yang tajam terutama pada aktivitas menjawab pertanyaan dan soal-soal di LKS, beberapa siswa masih terlihat enggan melakukaannnya walau sudah diberikan motivasi oleh guru, tapi tetap aktif memberikan kontribusi dalam melakukan aktivitas diskusi kelas. Peningkatan aktivitas belajar dan nilai harian siswa dari siklus I ke siklus II memungkinkan karena proses pembelajaran kooperati tipe STAD yang telah dilaksanakan. Dan diperlukan peningkatan proses pembelajaran jika siklus III memungkinkan untuk diadakan.

\section{KESIMPULAN DAN SARAN \\ Simpulan}

Berdasarkan temuan hasil penelitian, maka penelitian tindakan kelas dapat ditarik kesimpulan : "Jika pada siswa kelas XII IPA2 SMA N 1 Sitiung dilakukan proses pembelajaran dengan menggunakan Model pembelajaran kooperatif tipe STAD maka terjadi peningkatan aktivitas belajar Matematika siswa dan sebagai dampaknya nilai hasil belajarnya pun meningkat".

\section{Saran}

Peneliti menyarankan untuk meningkatkan aktivitas belajar matematika guru dapat menerapkan model pembelajaran kooperatif tipe STAD. Dan guru juga terus untuk berinovasi dengan model - model pembelajaran lainnya.

\section{DAFTAR PUSTAKA}

Alpandie, Imansyah. 1984. Didaktik Metodik Pendidikan Umum. Surabaya: Usaha Nasional

Arikunto, Suharsimi. 2008. Dasar- Dasar Evaluasi Pendidikan. Jakarta: Bumi Aksara.

Erman Suherman dkk. 2001. Strategi pembelajaran Matematika Kontemporer. Bandung: FMIPA UPI 
Ibrahim, Muslimin. 2000. Pengajaran Berdasarkan Masalah. Surabaya: University Press

Lie, Anita. 2005. Cooperative Learning. Jakarta: PT. Gramedia

Maryunis, Aleks. 2000. Peranan Pemetaan Informasi Terhadap Prestasi Belajar Siswa SLTP Kodya Padang (Laporan Penelitian). Padang: Jurusan Matematika UNP

Muslimin. 2000. Pembelajaran Kooperatif. Surabaya: University Press.

Sardiman. 2001. Interaksi dan Motivasi Belajar Mengajar. Jakarta: PT. raja Grafindo Persada

Slameto. 2003. Belajar dan Faktor-faktor yang mempengaruhinya. Jakarta : Rineka Cipta. 